\title{
Photobacterium halotolerans sp. nov., isolated from Lake Martel in Spain
}

\author{
Correspondence \\ Raúl Rivas \\ raul@wwwedu-micro.usal.es
}

\author{
Raúl Rivas,† Paula García-Fraile, Pedro F. Mateos, \\ Eustoquio Martínez-Molina and Encarna Velázquez
}

Departamento de Microbiología y Genética, Lab. 209, Edificio Departamental de Biología, Campus Miguel de Unamuno, Universidad de Salamanca, 37007 Salamanca, Spain

\begin{abstract}
A halotolerant bacterium was isolated from a saline lake located in Mallorca, Spain. Cells of the strain, designated MACLO ${ }^{\top}$, were Gram-negative, rod-shaped and motile by means of polar flagella. Colonies of strain MACLO1 ${ }^{\top}$ were white to cream in TSA medium, turning brown after 7 days of incubation; they were blue in thiosulphate/citrate/bile salts/sucrose agar medium. A neighbour-joining phylogenetic analysis based on 16S rRNA gene sequences showed that strain MACL $01^{\top}$ belongs to the genus Photobacterium, in which it forms a distinct lineage together with Photobacterium rosenbergii and Photobacterium ganghwense (showing 96.9 and 96.2\% similarity, respectively). The most closely related taxon according to phylogenetic analysis of the $r p o A$ gene is also $P$. rosenbergii ( $90 \%$ similarity). The recA gene also showed low similarity (83.7, 83.4 and $82.4 \%$, respectively) with respect to those of Vibrio proteolyticus LMG $3772^{\top}$, Photobacterium leiognathii LMG $4228^{\top}$ and $P$. rosenbergii LMG $22223^{\top}$. Neighbour-joining phylogenetic analysis of the $r p o A$ and $\operatorname{rec} A$ genes confirms that strain $\mathrm{MACLO} 1^{\top}$ belongs to the genus Photobacterium, forming a branch together with $P$. rosenbergii. Strain MACLO $1^{\top}$ was able to grow in $0-8 \% \mathrm{NaCl}$. Growth occurred between 4 and $37{ }^{\circ} \mathrm{C}$ (optimum, $28^{\circ} \mathrm{C}$ ) and at pH 5-8.5. Luminescence was negative on marine agar. Strain MACLO1 ${ }^{\top}$ was found to be sensitive to the vibriostatic agent $\mathrm{O} / 129$. It reduced nitrate to nitrite, produced $\beta$-galactosidase and hydrolysed gelatin, but did not produce arginine dihydrolase, indole or acetoin. Strain MACLO1 ${ }^{\top}$ used several carbohydrates and fermented glucose, L-arabinose and sucrose. The most abundant fatty acids were summed feature 3 (32.6\%; comprising $C_{16: 1} \omega 7 c$ and/or $C_{15: 0}$ iso 2-OH), $C_{16: 0}(21 \cdot 2 \%)$ and $\mathrm{C}_{18: 1} \omega 7 c(19.9 \%)$. The $\mathrm{G}+\mathrm{C}$ content of the genomic DNA was $49 \cdot 8 \mathrm{~mol} \%$. On the basis of genotypic, phenotypic, chemotaxonomic and phylogenetic results, strain MACLO1 ${ }^{\top}$ $\left(=\mathrm{LMG} 22194^{\top}=\right.$ CECT $5860^{\top}$ ) should be classified as the type strain of a novel species of the genus Photobacterium, for which the name Photobacterium halotolerans sp. nov. is proposed.
\end{abstract}

There are currently 12 accepted Photobacterium species with validly published names, and these were isolated from aquatic and marine environments. The genus belongs to the family Vibrionaceae together with other genera that also contain species isolated from these habitats. In this study, we report the characterization of a novel isolate from the genus Photobacterium that was isolated from water collected from Lake Martel, a subterranean saline lake in Mallorca, Spain.

tPresent address: Laboratorium voor Microbiologie, Vakgroep Biochemie, Fysiologie en Microbiologie, Universiteit Gent, K. L. Ledeganckstraat 35, B-9000 Gent, Belgium.

The GenBank/EMBL/DDBJ accession number for the 16S rRNA gene sequence of strain MACL01 ${ }^{\top}$ is AY551089.

An electron micrograph, neighbour-joining trees based on partial recA and $r p o A$ gene sequences and a table of the differential phenotypic characteristics of strain $\mathrm{MACLO} 1^{\top}$ are available as supplementary material in IJSEM Online.
Lake Martel was formed by filtration from the Mediterranean Sea through underground rocks and is one of the largest subterranean lakes in the world, being approximately $177 \mathrm{~m}$ in length; the width is approximately $30 \mathrm{~m}$ and the depth is $5-12 \mathrm{~m}$. The water of Lake Martel contains about $0.4 \% \mathrm{NaCl}$ and maintains a constant temperature of about $18{ }^{\circ} \mathrm{C}$ throughout the year. The bacterial diversity of this ecosystem remains unknown, although a species from a novel genus, Martelella mediterranea, was recently isolated from this environment (Rivas et al., 2005).

Strain MACL01 ${ }^{\mathrm{T}}$ was isolated under aseptic conditions from water samples taken from Lake Martel at a depth of $10 \mathrm{~cm}$. A $200 \mathrm{ml}$ sample was filtered, under vacuum in sterile conditions, through a membrane filter (Millipore) with a pore diameter of $45 \mu \mathrm{m}$. The membrane was placed on a plate containing YED medium (yeast extract, $0.5 \%$; glucose, $0.7 \%$; agar, $2 \%$ ) supplemented with $1.5 \%(\mathrm{w} / \mathrm{v}) \mathrm{NaCl}$ and 
was incubated at $28{ }^{\circ} \mathrm{C}$. Colony morphology was examined in cultures grown on TSA medium (BD Difco) supplemented with $1.5 \%(\mathrm{w} / \mathrm{v}) \mathrm{NaCl}$. To test the ability to grow in TCBS, strain MACL01 ${ }^{\mathrm{T}}$ was tested for growth on thiosulphate/citrate/bile salts/sucrose agar (TCBS; BD Difco) plates by incubating them $48 \mathrm{~h}$ at $28^{\circ} \mathrm{C}$.

Isolate MACL01 ${ }^{\mathrm{T}}$ was observed under a phase-contrast microscope after $48 \mathrm{~h}$ growth in YED medium at $22^{\circ} \mathrm{C}$ to check for cell shape and motility. The cells were also stained according to the classic Gram procedure described by Doetsch (1981). For electron microscopy, cells were grown on nutrient agar for 2 days at $22^{\circ} \mathrm{C}$. Cells were gently suspended in sterile water and then stained with $0.2 \%$ uranyl acetate and examined at $80 \mathrm{kV}$ with a Zeiss EM 209 transmission electron microscope (Peix et al., 2003).

Extraction and amplification of genomic DNA for $16 \mathrm{~S}$ rRNA sequence analysis were carried out as described previously (Rivas et al., 2003) and the recA and rpoA genes were amplified and sequenced as described by Thompson et al. (2005a, b). The sequences of these genes were compared against the sequences available from GenBank using the BLASTN programme (Altschul et al., 1990) and were aligned using CLUSTAL X software (Thompson et al., 1997). Distances were calculated according to Kimura's method (Kimura, 1980). Phylogenetic trees were inferred using the neighbourjoining method (Saitou \& Nei, 1987). Bootstrap analysis was based on 1000 resamplings. The MEGA2 package (Kumar et al., 2001) was used for all analyses.

DNA for the determination of $\mathrm{G}+\mathrm{C}$ content was prepared according to Chun \& Goodfellow (1995); the value was obtained by using the thermal denaturation method (Mandel \& Marmur, 1968).

For fatty acids analyses, strain MACL01 ${ }^{\mathrm{T}}$ was cultivated for $24 \mathrm{~h}$ at $28{ }^{\circ} \mathrm{C}$ in TSB (BD Difco) amended with $1.5 \%$ agar. The cellular fatty acids of strain MACL $01^{\mathrm{T}}$ were analysed as methyl esters by GLC analysis at the Deutsche Sammlung von Mikroorganismen und Zellkulturen (Braunschweig, Germany) according to the instructions of the Microbial Identification System (MIDI). Physiological and biochemical tests were performed using various API strips (bioMérieux). The API 20NE strip (Seo et al., 2005) was inoculated according to the manufacturer's instructions, without salt addition, with a suspension of strain MACL01 ${ }^{\mathrm{T}}$ in sterile water containing $1.5 \% \mathrm{NaCl}$. For the inoculation of API ZYM strips (Thompson et al., 2005b), suspensions of strain MACL01 ${ }^{\mathrm{T}}$ incubated for $48 \mathrm{~h}$ in TSA plus $1.5 \% \mathrm{NaCl}$ were obtained according to the manufacturer's instructions. Finally, for the inoculation of the API 50CH strip, a suspension in AUX medium plus $1.5 \% \mathrm{NaCl}$ was used. The API 20NE, API $20 \mathrm{E}$ and API $50 \mathrm{CH}$ strips were incubated for 48 and $72 \mathrm{~h}$ : the results were identical for both of these incubation times. The temperature range for growth was determined by incubating cultures in YED medium between 4 and $45^{\circ} \mathrm{C}$. The $\mathrm{pH}$ range was determined in YED medium, with a final $\mathrm{pH}$ between 4 and 10. Salt tolerance was studied in YED medium containing $0-12 \%(\mathrm{w} / \mathrm{v}) \mathrm{NaCl}$. Luminescence was observed in the dark on MA (BD Difco), in agreement with Macián et al. (2001). Standard phenotypic tests were performed as described previously (Baumann \& Schubert, 1984; Farmer \& Hickman-Brenner, 1992; Thompson et al., 2002a, b, 2005b). Resistance to the vibriostatic agents $\mathrm{O} / 129$ (10 and $150 \mu \mathrm{g}$; Oxoid) and novobiocin (5 $\mu$; Oxoid) was tested on MA medium.

Strain MACL $01^{\mathrm{T}}$ comprised cells that were Gram-negative, rod-shaped $(1.7 \times 0.7 \mu \mathrm{m})$ and motile by means of two polar flagella (see Supplementary Fig. S1 available in IJSEM Online).

According to the 16S rRNA gene sequence analysis, the organism under study belongs to the genus Photobacterium and forms a branch within this genus together with Photobacterium rosenbergii and Photobacterium ganghwense (Fig. 1). Strain MACL01 ${ }^{\mathrm{T}}$ shows 96.9 and $96 \cdot 2 \% 16 \mathrm{~S}$ rRNA gene sequence similarity with $P$. rosenbergii LMG $22223^{\mathrm{T}}$ and $P$. ganghwense $\mathrm{FR} 1311^{\mathrm{T}}$, respectively. These values are close to the cut-off value of $97 \%$ for bacterial species definition (Stackebrandt \& Goebel, 1994) and, hence, even though they suggested that the novel isolate could belong to a novel species of the genus Photobacterium, we analysed other housekeeping genes useful in the differentiation of Vibrio and related species (Thompson et al., 2004, 2005a, b).

The rpoA gene sequence analysis supports the phylogenetic position of strain MACL01 $1^{\mathrm{T}}$ within the genus Photobacterium as it shows $90.0 \%$ similarity with respect to $P$. rosenbergii LMG $22223^{\mathrm{T}}$ (Supplementary Fig. S2). The remaining species of the genus Photobacterium showed less than $88 \%$ similarity. This result is in agreement with those obtained by $16 \mathrm{~S}$ rRNA gene sequence analysis and coincides with those obtained by other workers, and indicates that rpoA gene sequences correlate well with 16S rRNA gene sequences (Zeigler, 2003; Thompson et al., 2005b). In the bacterial genomes sequenced to date, the rpoA gene is a ubiquitous single-copy gene that seems to be resistant to lateral gene transfer (Lerat et al., 2003; Zeigler, 2003; Gevers et al., 2004). Accordingly, it has recently been proposed as an alternative marker for bacterial classification and as a chronometer in Vibrio-like species (Thompson et al., 2005a).

The recA gene has been also proposed as an alternative marker in the family Vibrionaceae, and its sequences seem to be more discriminatory than those of the 16S rRNA gene in the genus Vibrio (Thompson et al., 2004). A pairwise analysis of the recA sequence of strain $\mathrm{MACL}^{\mathrm{T}}{ }^{\mathrm{T}}$ also revealed low levels of similarity between this strain and several species from the genera Vibrio and Photobacterium. For example, the analysis pointed to $83.7 \%$ similarity with Vibrio proteolyticus LMG $3772^{\mathrm{T}}, 83 \cdot 4 \%$ similarity with Photobacterium leiognathii LMG $4228^{\mathrm{T}}$ and $82 \cdot 4 \%$ similarity with $P$. rosenbergii LMG $22223^{\mathrm{T}}$. Nevertheless, neighbour-joining phylogenetic analysis of the recA gene from strain MACL0 ${ }^{\mathrm{T}}$ showed that this strain clustered with several species of the genus Photobacterium (Supplementary Fig. S3). The results of the recA analysis confirm those 


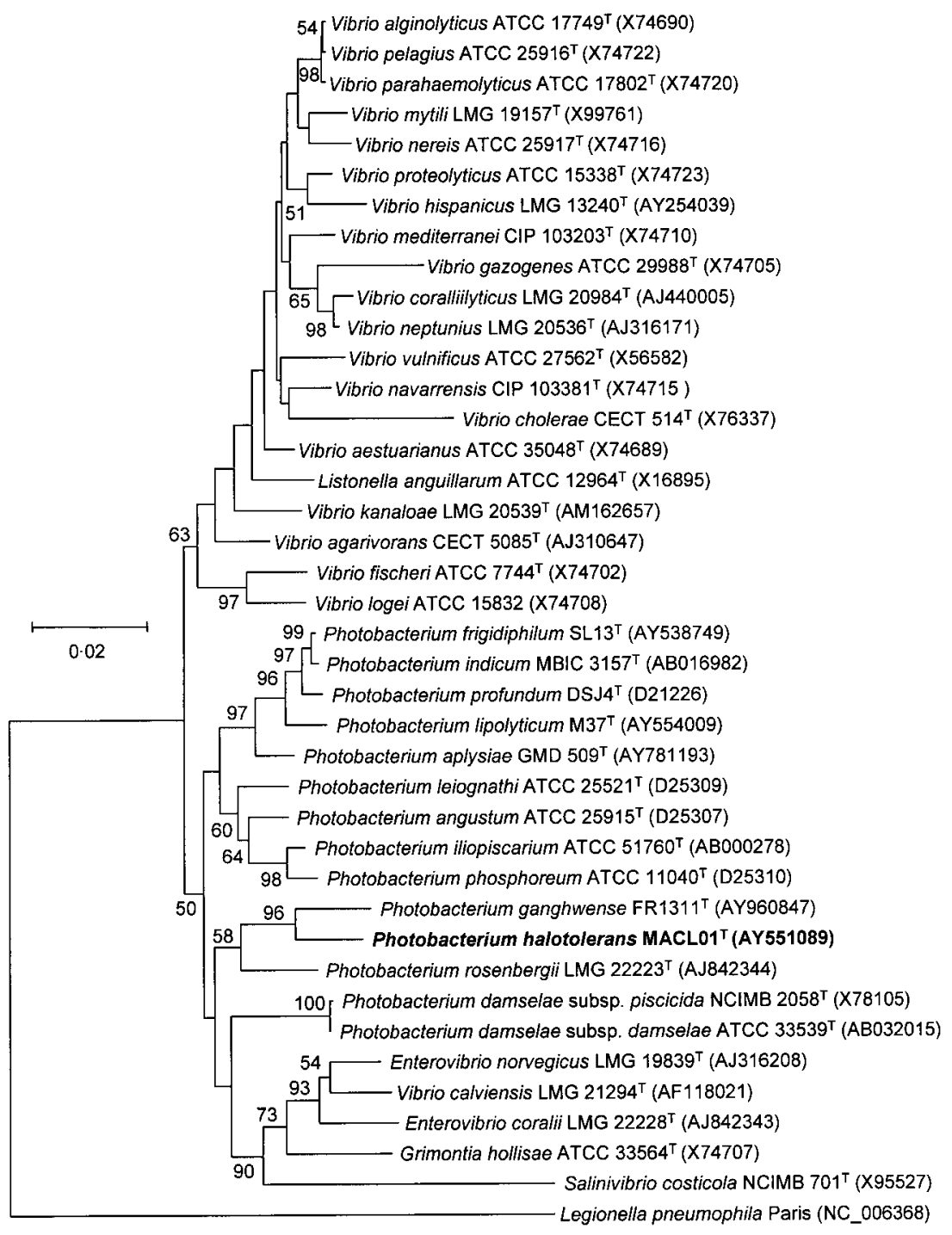

Fig. 1. Neighbour-joining tree based on nearly complete $16 \mathrm{~S}$ rRNA gene sequences of strain $\mathrm{MACLO}^{\top}$ and other related organisms of the family Vibrionaceae. The significance of each branch is indicated by a bootstrap percentage calculated for 1000 subsets. Bar, 2 nucleotide substitutions per 100 nucleotides. obtained by other workers (Thompson et al., 2004, 2005a, b), and show that Photobacterium and Vibrio are two different phylogenetic groups, although Photobacterium species did not form a homogeneous group.

According to Thompson et al. (2005a), there is variation of about 0.4 and $5.5 \%$ among strains from $P$. rosenbergii species in $r p o A$ and recA sequences, respectively. The lower similarity values found between the sequences of these two genes of $P$. rosenbergii and MACL $01^{\mathrm{T}}$ confirm that this strain does not belong to $P$. rosenbergii. Therefore, analysis of the 16S rRNA, rpoA and recA genes indicates that strain MACL01 ${ }^{\mathrm{T}}$ belongs to a novel species of the genus Photobacterium.

The DNA G $+\mathrm{C}$ content of strain MACL01 ${ }^{\mathrm{T}}$ is $49.8 \mathrm{~mol} \%$, which is slightly higher than those reported for the remaining species of the genus Photobacterium.

The results of the fatty acid methyl ester analysis are given in the species description below. The fatty acid composition of strain MACL01 ${ }^{\mathrm{T}}$ displayed qualitative and quantitative differences with respect to the species to which it is most closely related phylogenetically, namely $P$. rosenbergii and $P$. ganghwense. The main differences between strain MACL0 ${ }^{\mathrm{T}}$ and its closest relatives were as follows. Some fatty acids detected in $P$. rosenbergii were not detected in strain MACL01 $^{\mathrm{T}}$, e.g. $\mathrm{C}_{15: 0}, \mathrm{C}_{15: 0}$ iso, $\mathrm{C}_{15: 0}$ iso $3-\mathrm{OH}$ and $\mathrm{C}_{17: 1} \omega 9 \mathrm{c}$ iso. The fatty acid $\mathrm{C}_{16: 0}$ was detected in larger amounts in strain MACL01 ${ }^{\mathrm{T}}$ and P. ganghwense $(21 \%)$ than in $P$. rosenbergii (10-15\%). In contrast, the amount of fatty acids detected from summed feature 3 (comprising $\mathrm{C}_{16: 1} \omega 7 c$ and/or $\mathrm{C}_{15: 0}$ iso 2-OH) was larger in $P$. rosenbergii $(41-44 \%)$ than in strain MACL01 ${ }^{\mathrm{T}}(32 \cdot 6 \%)$ and P. ganghwense $(27 \cdot 8 \%)$. The amount of fatty acid $\mathrm{C}_{18: 1} \omega 7 c(29 \cdot 6 \%)$ was larger in $P$. ganghwense than in $P$. rosenbergii (23\%) and strain MACL01 ${ }^{\mathrm{T}}(20 \%)$. Finally, some fatty acids that were detected in amounts greater than $1 \%$ in strain MACL0 ${ }^{\mathrm{T}}$, such as $\mathrm{C}_{16: 1} \omega 9 c(2 \cdot 5 \%), \mathrm{C}_{16: 0}$ iso $(1 \%)$ and an unknown fatty acid at $12 \cdot 484(1 \cdot 2 \%)$, were not found for P. rosenbergii or P. ganghwense. 
The phenotypic characteristics of strain MACL $01^{\mathrm{T}}$ are given in the species description below. The strain differed from $P$. rosenbergii and $P$. ganghwense in several physiological and biochemical respects. Colonies of strain MACL $01^{\mathrm{T}}$ on TCBS plates were blue, those of $P$. rosenbergii were yellow and those of $P$. ganghwense were green. In contrast with $P$. rosenbergii, strain MACL $01^{\mathrm{T}}$ grew at $4{ }^{\circ} \mathrm{C}$ and was able to grow at $8 \%$ $\mathrm{NaCl}$. Strain MACL01 ${ }^{\mathrm{T}}$ produced gelatinase and fermented L-arabinose whereas $P$. rosenbergii did not. Strain MACL01 ${ }^{\mathrm{T}}$ did not produce arginine dihydrolase, esterase, esterase lipase, valine arylamidase or naphthol-AS-BI-phosphohydrolase, whereas these compounds were produced by $P$. rosenbergii. Strain MACL0 ${ }^{\mathrm{T}}$ did not ferment melibiose, L-rhamnose or amygdalin and did not assimilate cellobiose, galactose, mannose, melibiose, raffinose or methyl $\alpha$-D-glucoside. These tests were positive for $P$. rosenbergii. Strain MACL $01^{\mathrm{T}}$ differed from $P$. ganghwense in terms of growth at $4{ }^{\circ} \mathrm{C}$. Indole and arginine dihydrolase were not produced by strain MACL $01^{\mathrm{T}}$ but were assimilated or produced by $P$. ganghwense. Strain MACL $01^{\mathrm{T}}$ produced $\beta$-galactosidase and fermented sucrose and L-arabinose, unlike $P$. ganghwense. Several differential phenotypic characteristics of strain MACL $01^{\mathrm{T}}$ and the remaining Photobacterium species are shown in Supplementary Table S1.

In conclusion, the overall results of the present study indicate that isolate MACL $01^{\mathrm{T}}$ should be classified within a novel species, for which the name Photobacterium halotolerans sp. nov. is proposed.

\section{Description of Photobacterium halotolerans sp. nov.}

Photobacterium halotolerans (ha.lo.to'le.rans. Gr. n. hals salt; L. part. adj. tolerans tolerating; N.L. part. adj. halotolerans referring to the ability to tolerate high salt concentrations).

Cells are rod-shaped, Gram-negative and motile by means of polar flagella. Colonies on TSA supplemented with $1 \cdot 5 \%$ $(\mathrm{w} / \mathrm{v}) \mathrm{NaCl}$ are circular, smooth, white to cream in colour, opaque and usually $2-4 \mathrm{~mm}$ in diameter within 2 days at $28^{\circ} \mathrm{C}$. The isolate grows on TCBS medium, producing blue colonies. Oxidase- and catalase-positive. The DNA $\mathrm{G}+\mathrm{C}$ content of the type strain is $49 \cdot 8 \mathrm{~mol} \%$. Aerobic or facultatively anaerobic, chemo-organotrophic, mesophilic and halotolerant. Able to ferment carbohydrates. Negative Voges-Proskauer reaction and negative for indole production and $\mathrm{H}_{2} \mathrm{~S}$ production. Does not produce arginine dihydrolase, lysine decarboxylase, ornithine decarboxylase, caseinase, urease, esterase, esterase lipase, valine arylamidase, cystine arylamidase, trypsin, chymotrypsin, phosphohydrolase or glucuronidase. Gelatin is hydrolysed and the hydrolysis of aesculin is weak. The strain produces amylases, $\beta$-galactosidase, acid and alkaline phosphatase, leucine arylamidase and $\beta$-glucosaminidase. Positive for reduction of nitrate to nitrite; tryptophan deaminase production is weak. Negative for luminescence on marine agar. Grows in the presence of $\mathrm{NaCl}$ concentrations up to $8 \%(\mathrm{w} / \mathrm{v})$ and optimally in the presence of $1.5 \%(\mathrm{w} / \mathrm{v}) \mathrm{NaCl}$ at $28{ }^{\circ} \mathrm{C}$, although salt is not essential for growth. Growth occurs at $4-37^{\circ} \mathrm{C}$ (optimal growth occurs at $28^{\circ} \mathrm{C}$ ), at $\mathrm{pH} 5-8.5$ (optimal growth occurs at $\mathrm{pH} 7$ ). Shows sensitivity to the vibriostatic agent $\mathrm{O} / 129$ and is novobiocin-positive. The most abundant fatty acids are summed feature $3(32 \cdot 6 \%$; comprising $\mathrm{C}_{16: 1} \omega 7 \mathrm{c}$ and/or $\mathrm{C}_{15: 0}$ iso $\left.2-\mathrm{OH}\right), \mathrm{C}_{16: 0}(21 \cdot 2 \%)$, $\mathrm{C}_{18: 1} \omega 7 c(19 \cdot 9 \%), \mathrm{C}_{12: 0} 3-\mathrm{OH}(6 \cdot 6 \%)$ and $\mathrm{C}_{12: 0}(5 \cdot 9 \%)$. The following fatty acids were detected in small amounts: summed feature $2\left(3.0 \%\right.$; comprising $\mathrm{C}_{14: 0} 3-\mathrm{OH}, \mathrm{C}_{16: 1}$ iso $\mathrm{I}$, an unidentified fatty acid with an equivalent chain length of 10.928 and/or $\mathrm{C}_{12: 0}$ ALDE), $\mathrm{C}_{16: 1} \omega 9 c(2.5 \%)$, an unidentified fatty acid with an equivalent chain length of $12 \cdot 484(1 \%), \mathrm{C}_{16: 0}$ iso $(1 \%)$ and $\mathrm{C}_{14: 0}(1 \%)$. Ferments glucose, mannitol, sucrose and L-arabinose. Uses $\mathrm{N}$ acetylglucosamine, citrate, adipate, glucose, malate, maltose, mannitol, phenylacetate, sucrose, fructose and trehalose as sole carbon sources. Utilization of L-arabinose, D-ribose, D-xylose, gentiobiose, starch and glycogen is weak. Does not use amygdalin, caproate, D-arabinose, L-xylose, L-rhamnose, galactose, sorbose, D-mannose, melibiose, cellobiose, lactose, melezitose, raffinose, turanose, lyxose, tagatose, D-fucose, L-fucose, methyl $\alpha$-D-xyloside, methyl $\alpha$-Dmannoside, methyl $\alpha$-D-glucoside, arbutin, salicin, inulin, adonitol, inositol, sorbitol, dulcitol, erythritol, xylitol, arabinitol, glycerol and 2-ketogluconate or 5-ketogluconate as carbon sources.

The type strain, MACL $01^{\mathrm{T}}\left(=\mathrm{LMG} 22194^{\mathrm{T}}=\right.$ CECT $\left.5860^{\mathrm{T}}\right)$, was isolated from Lake Martel, Mallorca, Spain.

\section{Acknowledgements}

This work was supported by the CAICYT-DGES and the JCyL (Spanish Government). We are grateful to the staff at Deutsche Sammlung von Mikroorganismen und Zellkulturen for the chemotaxonomic analyses. We also thank N. Skinner for correction of the English version of the manuscript.

\section{References}

Altschul, S. F., Gish, W., Miller, W., Myers, E. W. \& Lipman, D. J. (1990). Basic local alignment search tool. J Mol Biol 215, 403-410.

Baumann, P. \& Schubert, R. H. W. (1984). Family II. Vibrionaceae Veron 1965, 5245 ${ }^{\mathrm{AL}}$. In Bergey's Manual for Systematic Bacteriology, vol. 1, pp. 517-545. Edited by N. R. Krieg \& J. G. Holt. Baltimore: Williams \& Wilkins.

Chun, J. \& Goodfellow, M. (1995). A phylogenetic analysis of the genus Nocardia with $16 \mathrm{~S}$ rRNA sequences. Int J Syst Bacteriol 45, 240-245.

Doetsch, R. N. (1981). Determinative methods of light microscopy. In Manual of Methods for General Bacteriology, pp. 21-33. Edited by P. Gerhardt, R. G. E. Murray, R. N. Costilow, E. W. Nester, W. A. Wood, N. R. Krieg \& G. B. Phillips. Washington, DC: American Society for Microbiology.

Farmer, J. J., III \& Hickman-Brenner, F. W. (1992). The genera Vibrio and Photobacterium. In The Prokaryotes. A Handbook on the Biology of Bacteria: Ecophysiology, Isolation, Identification, and Applications, 2nd edn, pp. 2952-3011. Edited by A. Balows, H. G. Trüper, M. Dworkin, W. Harder \& K. H. Schleifer. New York: Springer. 
Gevers, D., Vandepoele, K., Simillion, C. \& van de Peer, Y. (2004). Gene duplication and biased functional retention of paralogs in bacterial genomes. Trends Microbiol 12, 148-154.

Kimura, M. (1980). A simple method for estimating evolutionary rates of base substitutions through comparative studies of nucleotide sequences. J Mol Evol 16, 111-120.

Kumar, S., Tamura, K., Jakobsen, I. B. \& Nei, M. (2001). Molecular Evolutionary Genetics Analysis software. Tempe, AZ: Arizona State University.

Lerat, E., Daubin, V. \& Moran, N. A. (2003). From gene trees to organismal phylogeny in prokaryotes: the case of the $\gamma$-Proteobacteria. PLoS Biol 1, E19.

Macián, M. C., Ludwig, W., Aznar, R., Grimont, P. A. D., Schleifer, K. H., Garay, E. \& Pujalte, M. J. (2001). Vibrio lentus sp. nov., isolated from Mediterranean oysters. Int J Syst Evol Microbiol 51, 1449-1456.

Mandel, M. \& Marmur, J. (1968). Use of ultraviolet absorbance temperature profile for determining the guanine plus cytosine content of DNA. Methods Enzymol 12B, 195-206.

Peix, A., Rivas, R., Mateos, P. F., Martínez-Molina, E., RodríguezBarrueco, C. \& Velázquez, E. (2003). Pseudomonas rhizosphaerae sp. nov., a novel species that actively solubilizes phosphate in vitro. Int J Syst Evol Microbiol 53, 2067-2072.

Rivas, R., Sánchez, M., Trujillo, M. E., Zurdo-Piñeiro, J. L., Mateos, P. F., Martínez-Molina, E. \& Velázquez, E. (2003). Xylanimonas cellulosilytica gen. nov., sp. nov., a xylanolytic bacterium isolated from a decayed tree (Ulmus nigra). Int J Syst Evol Microbiol 53, 99-103.

Rivas, R., Sánchez-Márquez, S., Mateos, P. F., Martínez-Molina, E. \& Velázquez, E. (2005). Martelella mediterranea gen. nov., sp. nov., a novel $\alpha$-proteobacterium isolated from a subterranean saline lake. Int J Syst Evol Microbiol 55, 955-959.

Saitou, N. \& Nei, M. (1987). The neighbor-joining method: a new method for reconstructing phylogenetic trees. Mol Biol Evol 4, 406-425.

Seo, H. J., Bae, S. S., Lee, J. Y. \& Kim, S. J. (2005). Photobacterium frigidiphilum sp. nov., a psychrophilic, lipolytic bacterium isolated from deep-sea sediments of Edison Seamount. Int J Syst Evol Microbiol 55, 1661-1666.

Stackebrandt, E. \& Goebel, B. M. (1994). Taxonomic note: a place for DNA-DNA reassociation and 16S rRNA sequence analysis in the present species definition in bacteriology. Int J Syst Bacteriol 44, 846-849.

Thompson, J. D., Gibson, T. J., Plewniak, F., Jeanmougin, F. \& Higgins, D. G. (1997). The CLUSTAL_X windows interface: flexible strategies for multiple sequence alignment aided by quality analysis tools. Nucleic Acids Res 25, 4876-4882.

Thompson, F. L., Hoste, B., Vandemeulbroecke, K., Engelbeen, K., Denys, R. \& Swings, J. (2002a). Vibrio trachuri Iwamoto et al. 1995 is a junior synonym of Vibrio harveyi (Johnson and Shunk 1936) Baumann et al. 1981. Int J Syst Evol Microbiol 52, 973-976.

Thompson, F. L., Hoste, B., Thompson, C. C., Goris, J., Gomez-Gil, B., Huys, L., De Vos, P. \& Swings, J. (2002b). Enterovibrio norvegicus gen. nov., sp. nov., isolated from the gut of turbot (Scophthalmus maximus) larvae: a new member of the family Vibrionaceae. Int J Syst Evol Microbiol 52, 2015-2022.

Thompson, F. L., Thompson, C. C., Vandemeulebroecke, S., Hoste, K., Dawyndt, P. \& Swings, J. (2004). Use of recA as an alternative phylogenetic marker in the family Vibrionaceae. Int J Syst Evol Microbiol 54, 919-924.

Thompson, F. L., Gevers, D., Thompson, C. C., Dawyndt, P., Naser, S., Hoste, B., Munn, C. B. \& Swings, J. (2005a). Phylogeny and molecular identification of vibrios on the basis of multilocus sequence analysis. Appl Environ Microbiol 71, 5107-5115.

Thompson, F. L., Thompson, C. C., Naser, S., Hoste, B., Vandemeulebroecke, K., Munn, C., Bourne, D. \& Swings, J. (2005b). Photobacterium rosenbergii sp. nov. and Enterovibrio coralii sp. nov., vibrios associated with coral bleaching. Int J Syst Evol Microbiol 55, 913-1917.

Zeigler, D. R. (2003). Gene sequences useful for predicting relatedness of whole genomes in bacteria. Int J Syst Evol Microbiol 53, 1893-1900. 